\title{
VÝSKUM ZANIKNUTÉHO MINORITSKÉHO KOSTOLA A CINTORÍNA V RADE (OKRES TREBIŠOV)
}

\author{
PETER TAJKOV - JOZEF SUKENÍK
}

\begin{abstract}
Abstrakt: Príspevok predkladá výsledky výskumu zaniknutého minoritského kostola a pril'ahlého cintorína $v$ obci Rad v rokoch 2009-2013. Okrem odhalenia zaniknutej architektúry archeologický výskum odkryl niekol'ko hrobov. Kostry boli podrobené súdnoznaleckej expertize a spojené s písomnými prameňmi opisujúcimi násilnú smrt' mnichov. Samotný archeologický výskum zároveň podnietil archívny výskum týkajúci sa lokality, ktorý priniesol nové zistenia k dejinám misijnej činnosti františkánskej rehole na Zempline.
\end{abstract}

Kl'účové slová: kostol-minoritský kláštor - rekatolizácia-včasný novovek.

\section{Research into a Defunct Minorite Church and Graveyard in Rad (Trebišov District)}

Abstract: This article presents the results of research into a defunct Minorite church and an adjacent graveyard in the Rad village in 2009-2013. Apart from investigating architecture, the archaeological research disclosed several graves. The skeletal remains were subjected to forensic analysis and related to written records conveying a violent death of several monks. The investigation also triggered archive research into the location that brought new findings regarding the history of the missionary activities of the Franciscan order in the Zemplin region.

Key words: church - Minorite monastery - recatholization - early modern age.

\section{Lokalita}

Obec Rad sa nachádza v južnej časti Východoslovenskej nížiny, na nive Latorice, ktorá po sútoku s Ondavou vytvára Bodrog. Obec leží ned’aleko cesty Košice - Král'ovský Chlmec, severne od obce Svätá Mária. Intravilán Radu je pôvodne ostrovom, obkoleseným mŕtvymi ramenami a súvislým pásom pieskových dún $\mathrm{s}$ vinicami, ktoré sú charakteristickou súčastou krajinného reliéfu extravilánu (obr. 1,2). Skúmaný zaniknutý kostol a cintorín sa nachádzajú v priestore dnešnej farskej záhrady rímskokatolíckej fary, v severovýchodnej časti obce. V tesnom východnom susedstve lokality je vodná plocha mŕtveho ramena, pôvodne nazývaného Tice.

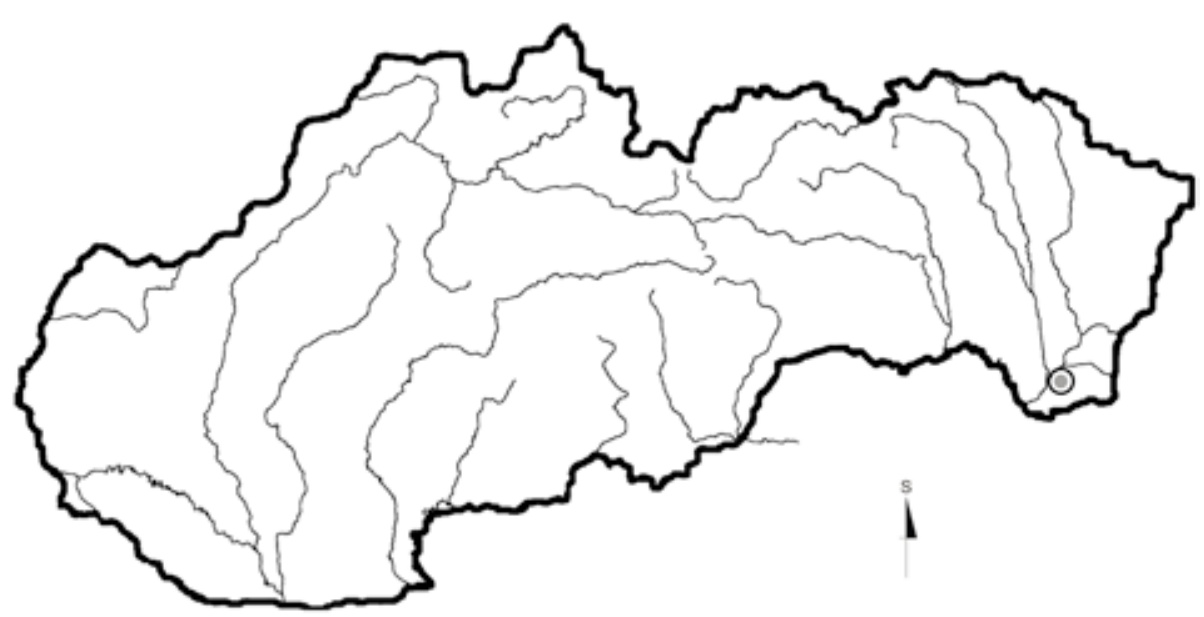

Obr. 1. Situovanie lokality.

Abb. 1. Lage der Fundstelle. 


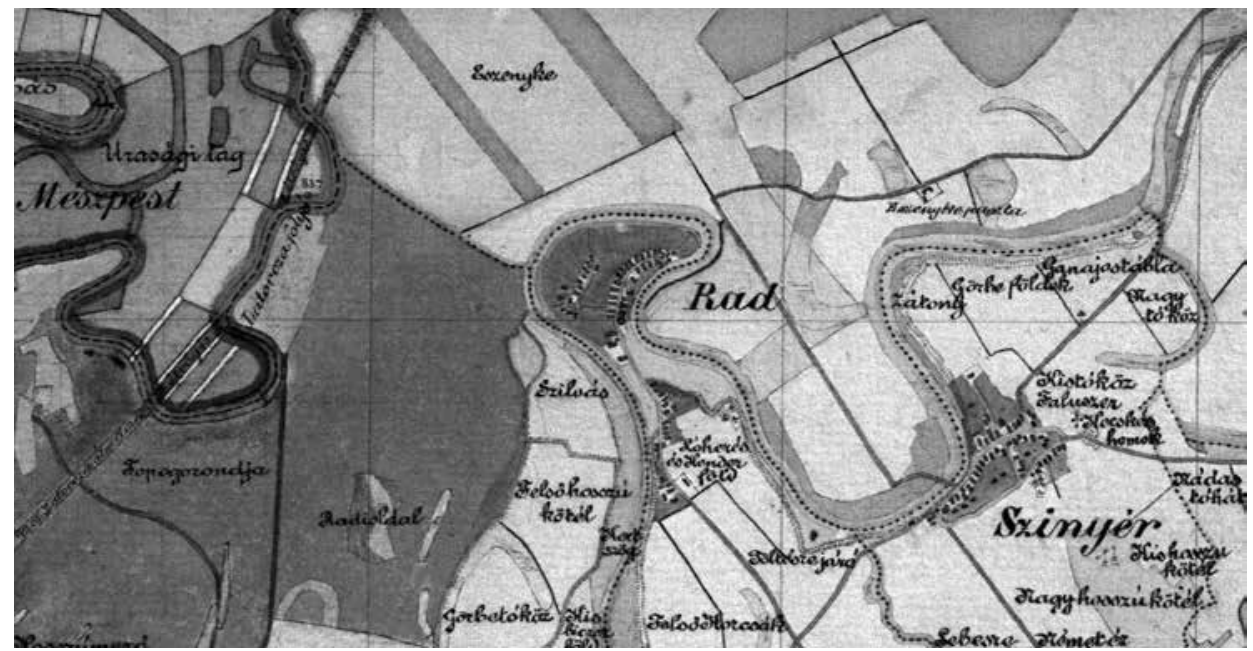

Obr. 2. Historická mapa Radu zo záveru 19. storočia. Zdroj https://Inyr.eleveltar.hu.

Abb. 2. Historische Karte von Rad vom Ende des 19. Jahrhunderts. Quelle https://nyr.eleveltar.hu.

Z pohl’adu archeológie je obec známa vd’aka viacerým významným pamiatkam. Pochádzajú z rôznych historických období a ich objavy sa viažu prevažne na spomínané pieskové duny. Piesková duna Hegyeshomok je známa ako polykultúrne sídlisko, doložené prieskumami od roku 1954. Najstaršie nálezy patria otomanskej kultúre zo staršej doby bronzovej. Ďalšie sú z doby laténskej, rímskej a včasného stredoveku. Duna nazývaná Cselédhomok bola výrazne poškodená t’ažbou piesku. Od roku 1978 na polohe vykonával záchranný výskum Archeologický ústav SAV. Preskúmal sa zvyšok osady z doby halštatskej, zo 7.-6. storočia BC. Na pieskovej dune v južnej časti extravilánu s názvom Vereshomok bolo v roku 1963 tažbou piesku porušené radové pohrebisko, datované mincami do prelomu 11. a 12. storočia. Počas prieskumu boli identifikované i nálezy z obdobia neolitu, doby halštatskej, rímskej a včasného stredoveku (Gačková 2004, 472-473).

Obec sa prvýkrát nepriamo v listinách uvádza v roku 1319 (terram Rod; Uličný 2001, 417). Farnost' sa podl'a poslednej edície súpisu pápežských desiatkov z 30-tych rokov 14. storočia od V. Sedláka spomína na troch miestach (MVS I., n. 807, 1101, 1306). Z nášho pohl'adu je však totožnost' Radu spomínaného v súpise medzi abovskými, a nie zemplínskymi obcami diskutabilná. S istotou sa kostol v obci spomína až v roku 1438 ako objekt bez veže a s cintorínom (in possessione Raad... ecclesiam lapideam sine turri...; Uličný 2001, 417).

Jedným z najcitovanejších prameňov týkajúcich sa priamo našej lokality je záznam uvedený v Súpise pamiatok na Slovensku, kde sa doslova píše: „V záhrade bývalého kláštora sú kamenné zvyšky románskej stavby menšieho kostola, ktorý sa spomína v archiváliách rodiny Soósovcov v roku 1438“ (Súpis III. 1969, 5). Ruiny chrámu vo farskej záhrade uvádzal aj M. Slivka spolu s A. Vallaškom (Slivka-Vallašek 1983, 155).

Významným prameňom, s ktorým sme boli konfrontovaný hned’ na začiatku výskumu, bola vyše 600 stranová farská kronika z obdobia rokov 1920-1957, spísaná vtedajším radským farárom Bélom Petrikom (1888-1971). Tento farár sa zaujímal o históriu minoritov v Rade a čerpal z archívov miestnych šlachtických rodín. Vytvoril dokonca náčrt pôdorysu zaniknutého kláštorného kostola a dnešnú budovu fary stotožnil s bývalou kláštornou budovou (obr. 3). Spomína aj príbeh umučenia niekol'kých minoritov z Radu s odvolaním sa na známy korpus zemplínskeho polyhistora Antona Szirmaya zo Szirmy o dejinách Zemplínskej župy z roku 1804 (Szirmay 1804, 232-235). 


\section{Minoritský kláštor v Rade vo svetle písomných prameňov}

Počiatok pôsobenia rehole minoritov (konventuálna vetva františkánskeho rádu) v Rade zapadá do obdobia rekatolizačných misií, ktoré organizovala Svätá stolica prostredníctvom rím-

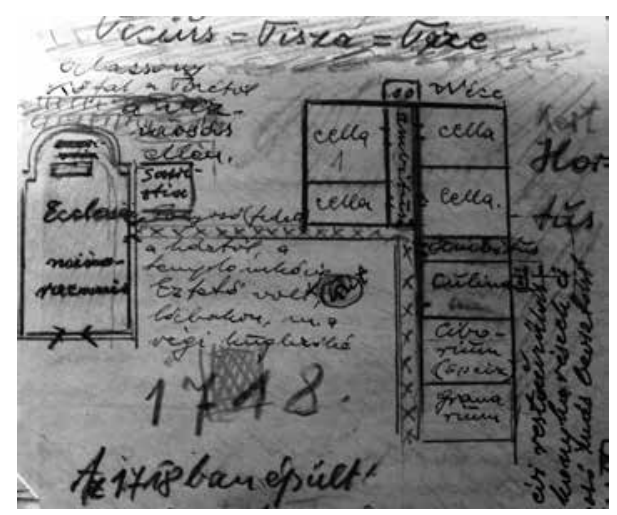

Obr. 3. Skica kláštora od Belu Peterika. Zdroj Farská kronika rímskokatolíckej fary Rad.

Abb. 3. Planskizze des Klosters von Bela Peterik. Quelle Pfarrchronik der römisch-katholischen Pfarrei Rad. skej kongregácie tzv. Propaganda Fide. Tento rímsky úrad vysielal do Uhorska rehol'ných kňazov obdarených mimoriadnymi jurisdikciami a privilégiami. Tí často vstupovali do služieb šlachtických rodín, ktoré im poskytovali hmotné zázemie a ochranu. Misionárom ale chýbala základňa, ktorá by ich oslobodila od závislosti na aristokratoch a umožnila im viest' kláštorný život. O založenie kláštora pre rád minoritov sa od roku 1633 snažili dvaja šlachtici, Juraj a Peter Melitovci (SOCG, 217218v č. 75; ASPF Roma).

Už na jar roku 1635 prebýval minorita Pietro Vallonica v ich kúrii v Rade (SOCG, $250 r-v+264 v$ č. 77; ASPF Roma). Vallonica prispôsobil čast' domu na ubytovací priestor pre reholníkov a vytvoril malú kaplnku (SOCG, 214r-v + 217v č. 78; ASPF Roma). V novembri roku 1635 bola kongregácia Propaganda Fide upovedomená, že Juraj Melit daroval svoju kúriu v Rade reholi minoritov (SOCG, 195r-v + 198v č. 78; ASPF Roma). Fundátor nariadil vystavat' v Rade chrám, ktorý mal byt' zasvätený svätej Sofii. Zároveň poprosil Svätú stolicu, aby chrám obdarovala odpustkami (SOCG, $99+100 v$ č. 78; ASPF Roma). Oficiálne cirkevné procesy vedúce $\mathrm{k}$ založeniu kláštora sa spomalili kvôli svojvol’nému odchodu provinciála Angela Petriccu do Talianska a kvôli vážnej chorobe iného predstaveného, komisára Radzinského (SOCG, 148-149v č. 79; ASPF Roma). Definitívne založenia kláštora sa podarilo na jeseň roku 1637. Podl'a fundačných listín mali v Rade žit’ štyria rehol'níci. Kláštor mal štatút rezidencie. Neskôr sa mal počet rehol'níkov zvýšit' (SOCG, $305+312 v$ č. 80; 306r-v č. 80; ASPF Roma). K rozšíreniu a zväčšeniu malo dôjst' po smrti Melita, ktorý vo svojom testamente zanechal rádu 500 florénov. (S/XXX-A, 28r-v č. 3; AGOFMConv. Roma).

Melit umrel 10. septembra 1638 (SOCG, $224+225$ v č. 81; ASPF Roma). Po jeho smrti príbuzní napadli platnost' testamentu a usilovali sa vyhnat' rehol'níkov a získat' dom do svojich rúk (SOCG, 232r-v + 249/v č. 81; ASPF Roma). Minoriti sa obrátili na palatína Esterházyho, ktorý sa diplomaticky vyhýbal zasahovaniu do sporu a navrhol riešenie finančným vyrovnaním. Komunita uvažovala o prest’ahovaní do Vranova (SOCG, 192-193v č. 82; ASPF Roma). Vel'kým šokom bolo zavraždenie jedného zo štyroch novicov tohto domu (SOCG, 454r-v + 459v č. 28; ASPF Roma), konvertitu Štefana Iglódiho, ktorého umučili kalvíni 6. novembra roku 1639 (SOCG, 228-233v č. 83; ASPF Roma). Správa o trápeniach rehol'níkov v Rade sa rýchlo rozšírila a bol o nej informovaný i samotný pápež Urban VIII. (Lettere e decreti della Sacra Congregazione Propaganda Fide e Biglietti di Mons. Segretario, 121v-122r č. 20; ASPF Roma).

Provinciálny minister Andreas Scalimoli da Castellana v zápise z provinciálnej vizitácie z roku 1641 poznamenáva, že rehol’ný dom v Rade nie je viazaný žiadnymi obligáciami, pretože obyvatel'stvo Radu je kalvínske. Dom má svoj kostol, sakristiu a vyvýšený chór, refektár, kuchyňu, pivnicu, sklad a jednu prekrásnu izbu, určenú pre predstaveného miestnej komunity. Okolo kláštora je vraj vel'mi pekná záhrada. Ned’aleko je sad, v ktorom bratia pestujú mnohé druhy ovocia. Vizitátor referuje, že spory s dedičmi fundátora stále pretrvávajú. V čase vizitácie obývali 
rezidenciu štyria bratia a kočiš. Mali štyri kone, jeden koč a žili len z milodarov. Scalimoli veril, že problémy sa vyriešia, lebo v správe pre generálneho ministra referuje o úmysle postavit' medzi Stropkovom a Radom v obci Kučín d’alšiu malú rezidenciu, ktorá by bola na polceste medzi dvoma konventmi (S/XXX-A, 2r-v-3r č. 1; AGOFMConv. Roma).

Počas stavovského povstania Juraja I. Rákociho v rokoch 1643-1645 boli minoriti z Radu vyhnaní. Po jeho skončení vyjednával o vrátení domu s Rákocim páter Agostino Pederzolli (SOCG, 285 č. 218; ASPF Roma). Ďalšie nepokoje zasiahli rehol'níkov počas povstania Juraja II. Rákociho, pravdepodobne v roku 1653. Podl'a neskorších správ, pochádzajúcich až z 18. storočia, boli vtedy v Rade zabití pátri Angelo da Sonnino, Antonius de Sociis, Bonaventura de Taurmina a iní traja, ktorých mená nie sú známe (Relatio de Statu Provinciae; APOFMConv. Miskolc). Ďalšie ozbrojené prepadnutie a vyrabovanie rezidencie sa udialo na počiatku Tekeliovho povstania. V roku 1679 totiž provinciálna kapitula v Spišskom Štvrtku rokovala o definitívnom opustení miesta, bratia však s návrhom nesúhlasili a činnost' vel'mi poškodeného domu sa rozhodli obnovit' (S/XXX-A, 482r-486v č. 2; AGOFMConv. Roma).

Svoje rozhodnutie museli opät' prehodnotit' v roku 1681. Povstalci totiž poškodili kláštor natol'ko, že budovy kostola a rezidencie boli úplne zničené. Navyše vojaci ublížili viacerým rehol'níkom (Cl. III, 141r-v č. 19; AGOFMConv Roma). Ozbrojené útoky na rezidenciu evidujeme aj v roku 1690, ked' rehol'níkov prepadli Rákociho vojaci a d'alšie v 90. rokoch 17. storočia, ked' rezidenciu opät' vyrabovali povstalci na čele s grófom Františkom Tokayom. Každý z týchto útokov stál život niekol'kých rehol'níkov (S/XXX-A, 482r-486v č. 2; AGOFMConv. Roma).

Posledné rabovania zasiahli komunitu v Rade roku 1710. Vtedy vraj šlachtic František Klobušický ubránil minoritov v Rade a zachránil ich písomnosti a spustošené majetky kostola i rezidencie pred heretikmi a príbuznými fundátora. Na mieste rezidencie sa v tom čase už vraj nenachádzalo nič, bratia však Rad i tak neopustili. Po skončení Rákociho povstania sa v roku

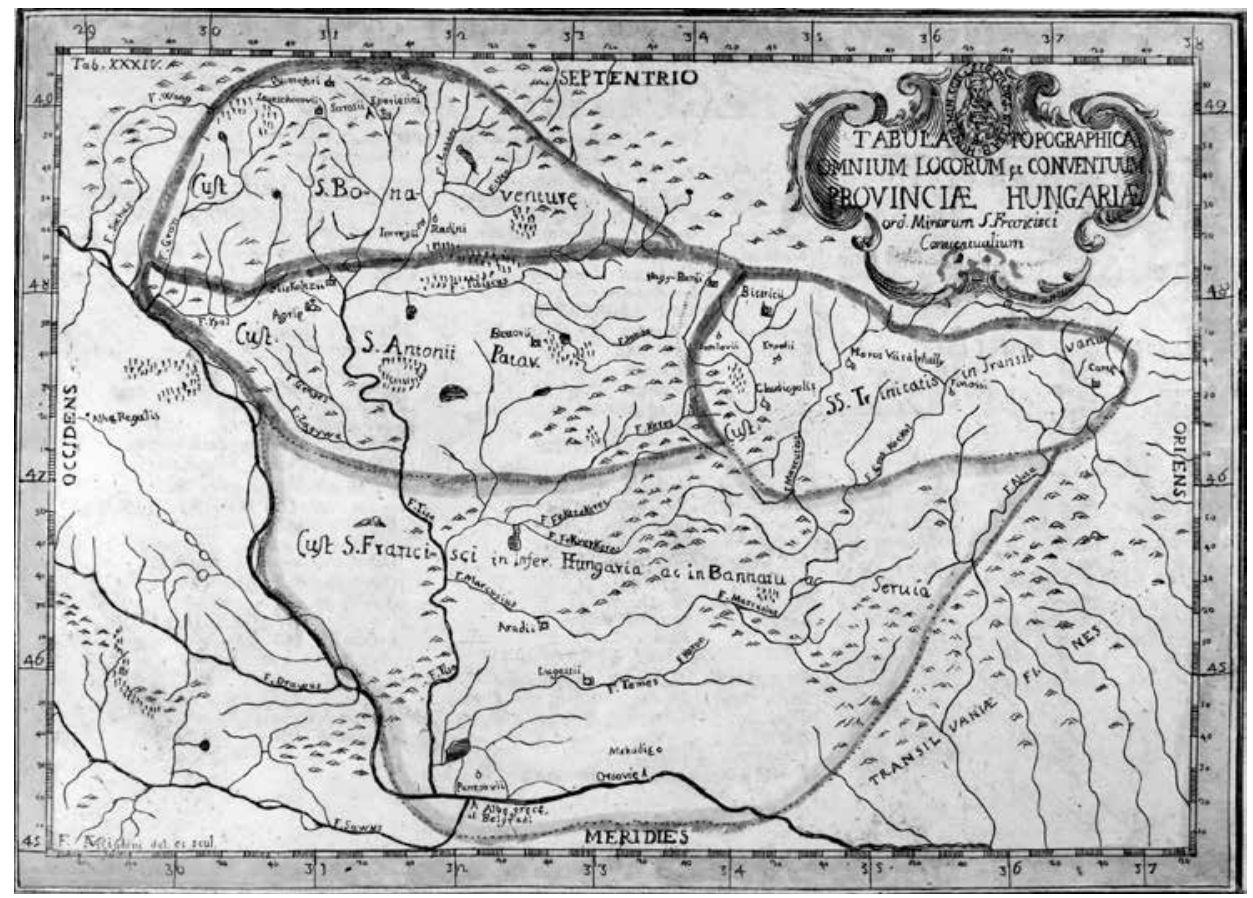

Obr. 4. Mapa uhorskej minoritskej provincie z roku 1771. Zdroj AGOFMConv.: R/b 27.

Abb. 4. Karte der ungarischen Minoritenprovinz aus dem Jahr 1771. Quelle AGOFMConv.: R/b 27. 
1711 pokúsili rezidenciu s pomocou milodarov obnovit' (S/XXX-A, 28r-v č. 3; AGOFMConv. Roma). Obnova sa podarila, pretože z apríla roku 1744 sa zachoval súpis inventáru rehol'ného domu i farského kostola, ktorý minoriti ešte stále spravovali (Pál 1744, 126r-132v).

Po prest’ahovaní kláštornej komunity z Radu do ned’alekého Brehova v roku 1767 figuruje stará rezidencia nad’alej v dokumentoch ako samostatný dom (obr. 4). Podl'a fundačných listín z Brehova mali byt' do Radu každoročne vysielaní dvaja pátri ako Capellani locali (Knáisz 1803, 389). Predstavení pre tento dom boli menovaní do roku 1797 (Knáisz 1803, 320-322). V roku 1818 bola duchovná správa farnosti Rad odovzdaná diecéznemu kléru (Hišem 2006, 326).

\section{Archeologický výskum}

V roku 2009 sme na lokalite vykonali menší záchranný archeologický výskum. Tento bol vyvolaný snahou farského úradu o stavebné rozšírenie budovy fary. Aj v tomto čase boli na lokalite zretel'né relikty po zaniknutej architektúre, najmä v jej východnej časti, kde bývalé rameno Tice vymylo profil brehu aj so zvyškami muriva. Následným výskumom sa nám podarilo odkryt' murivo, ktoré bolo interpretované ako západné murivo sakristie zaniknutého kostola. Na základe nálezov zlomkov keramiky bola najstaršia kultúrna vrstva zaradená do obdobia 17.-18. storočia.

Tieto výsledky spolu s indíciami o zaniknutom františkánskom kláštore vo farskej záhrade podnietili vlastníka k žiadosti o vykonanie archeologického výskumu na vedecké a dokumentačné účely s ciel'om odkryt' zvyšky predpokladaného kláštorného kostola v celom rozsahu. Tento výskum sme realizovali v roku 2011.

Výskum sme začali v spomínanej východnej časti lokality, v miestach terénneho zlomu, resp. profilu nad ramenom Tice. Po začistení profilu v ňom boli dobre viditel'né fragmenty muriva a kamenné bloky. Neskôr sme odkryli previazané murivá so šírkou $0,9 \mathrm{~m}$ (obr. 5). Zachytili sme tak šírku interiéru objektu, ktorý sme interpretovali ako svätyňu kostola, čiastočne previazanú s murivom bývalej sakristie, pristavanej $\mathrm{k}$ bývalej kláštornej budove - dnešnej fary. Zároveň sme tu odkryli bývalú oltárnu menzu a zvyšky kamennej dlážky svätyne. Následne sa nám podarilo zachytit' severné murivo lode zaniknutého kostola. Už v híbke pol metra sa nám podarilo zachytit’ korunu pomerne hrubého $(1,4 \mathrm{~m})$ kamenného muriva, spájaného kvalitnou maltou. Zistili sme, že sa čiastočne jedná o pôvodne nadzemné murivo, ked’že sme v híbke $0,7 \mathrm{~m}$ zachytili jeho základový odskok.

$\mathrm{V}$ tom čase sme odkryli aj prvý hrob - tesne pri severnom exteriérovom murive svätyne. Hrob č. 1 obsahoval orientovanú mužskú kostru vo vystretej polohe na chrbte s lebkou v neanatomickej polohe, s fragmentmi drevenej rakvy, spájanej železnými klincami (obr. 6).

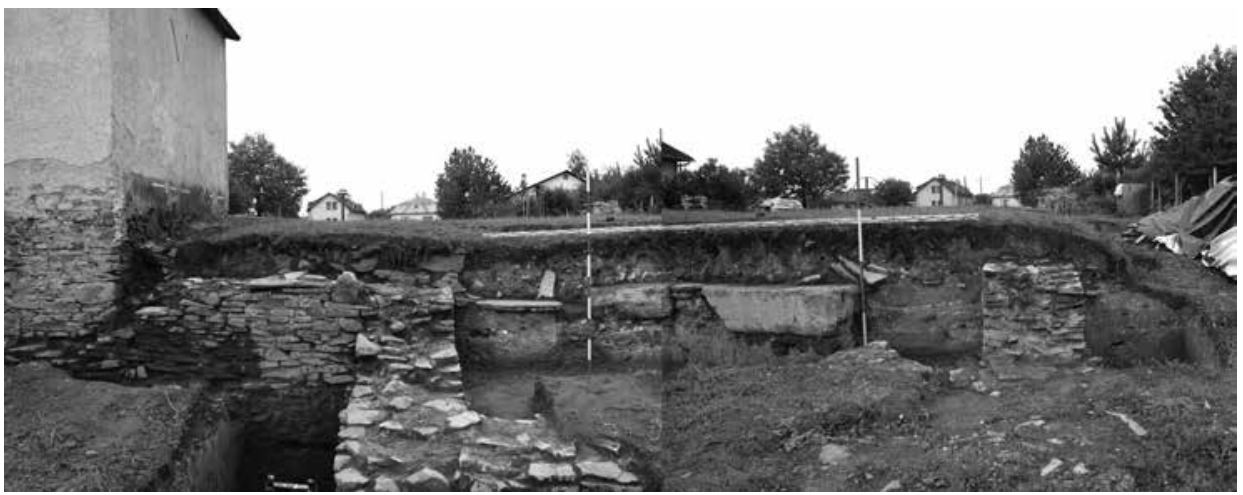

Obr. 5. Sonda S1, murivá svätyne a sakristie. Foto A. Balogh.

Abb. 5. Sondierschnitt S1, Mauerwerk des Altarraums und der Sakristei. Foto A. Balogh. 


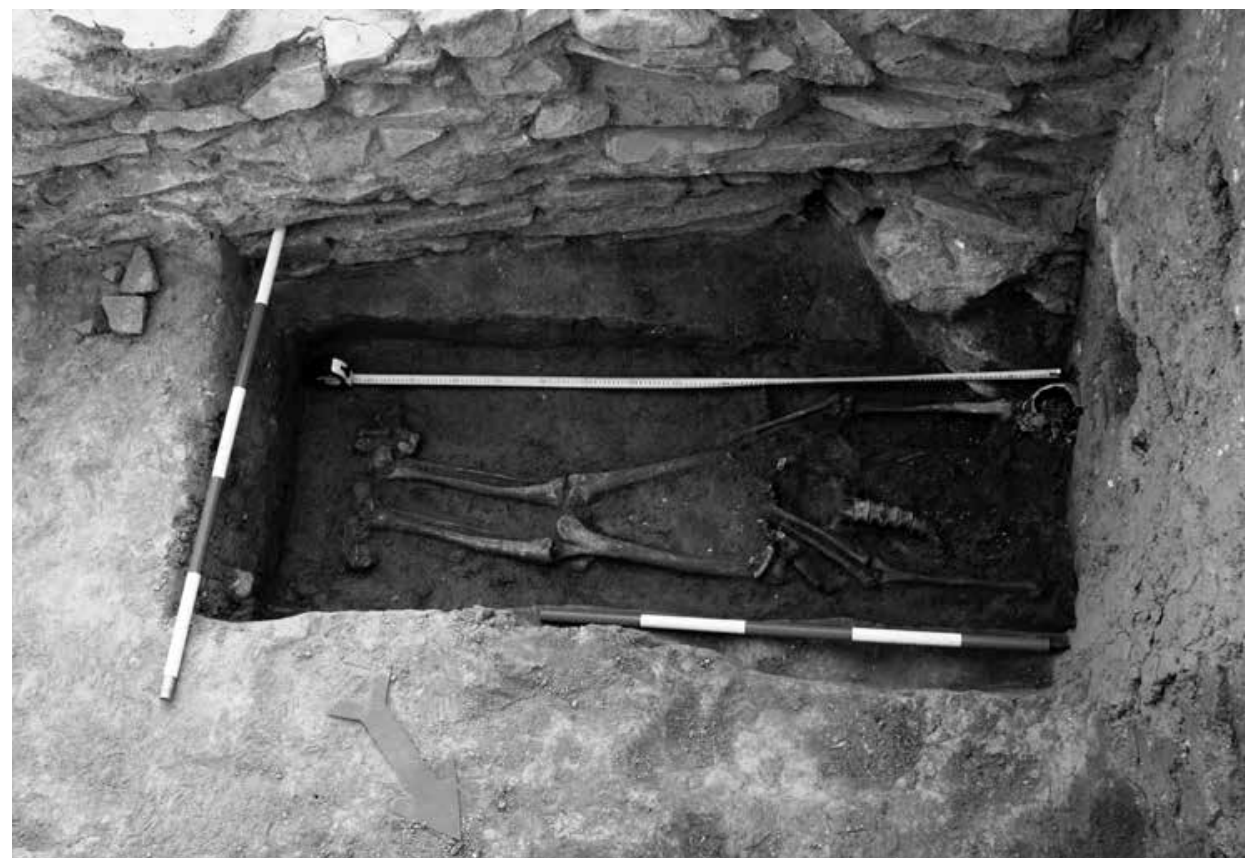

Obr. 6. Hrob č. 1. Foto A. Balogh.

Abb. 6. Grab Nr. 1. Foto A. Balogh.

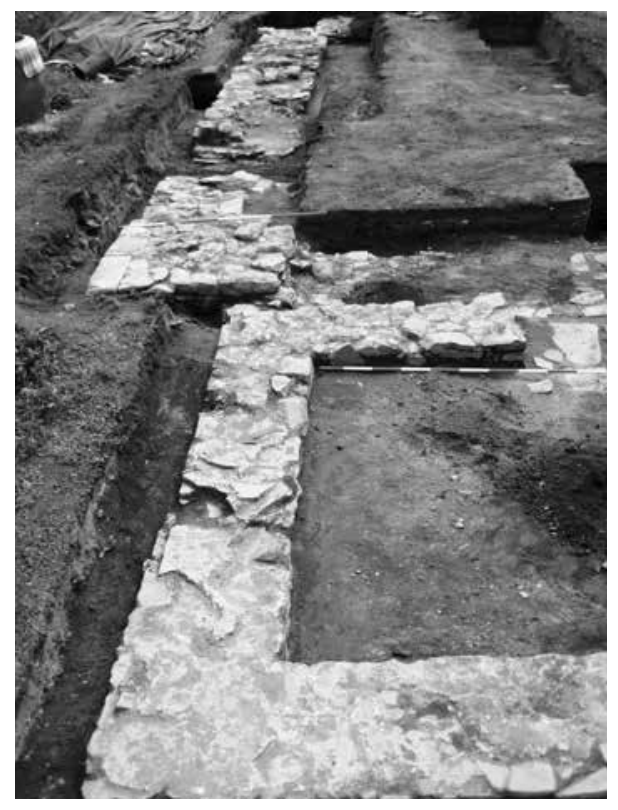

Obr. 7. Murivo veže a lode kostola. Foto A. Balogh.

Abb. 7. Mauerwerk des Turms und des Kirchenschiffs. Foto A. Balogh.
V západnej časti lokality sme zachytili základové murivo v šírke $0,8 \mathrm{~m}$, ktoré sme neskôr interpretovali ako základ západnej veže bývalého kostola. Táto veža nebola previazaná so západným murivom lode kostola (obr. 7).

Čo sa týka spojenia lode a svätyne kostola, aj tu bola medzi oboma murivami zretel'ná cezúra (obr. 8, 9). Murivo svätyne malo odlišnú štruktúru, tvorenú lomovým kameňom, kladeným do nepravidelných riadkov, oproti výrazne širšiemu a murársky hrubšie prevedenému murivu lode. Objavili sme aj murivo vítazného oblúka, ktoré bolo postavené súčasne s murivom štvorcovej svätyne, i ked' bolo viackrát premurované. Pozoruhodná bola aj úroveň založenia svätyne, ktorá bola o vyše metra hlbšie ako u ostatných častí dispozície zaniknutej architektúry.

Charakteristiku vertikálnej stratigrafie lokality najlepšie vystihuje západný profil/ rez v priestore svätyne a sakristie skúmaného objektu a $\mathrm{v}$ miestach spomínaného terénneho zlomu nad ramenom Tice (obr. 10). Po odstránení zatrávnenej humusovej vrstvy sme tu zachytili hlinitú navážku (100), spojenú 


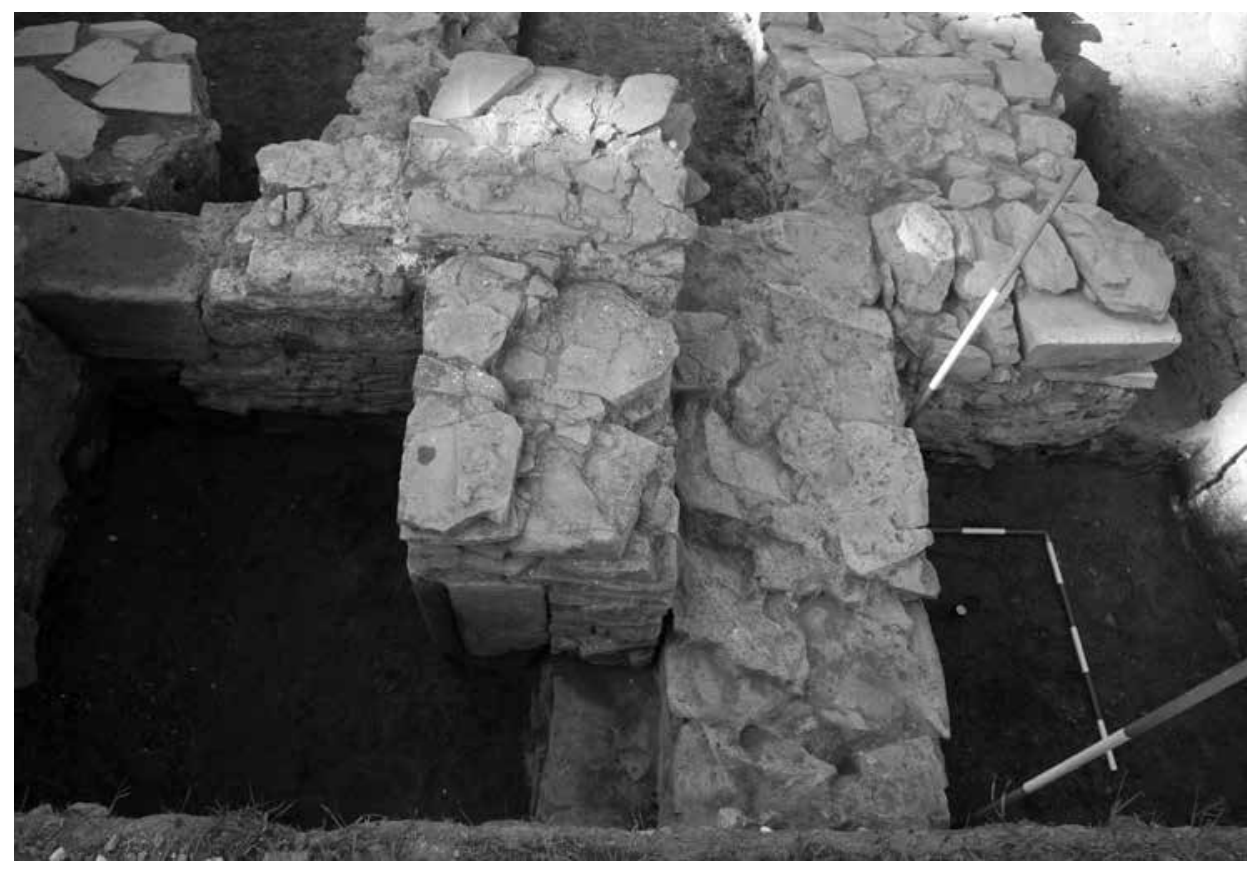

Obr. 8. Murivá svätyne, vít’azného oblúka a lode kostola. Foto A. Balogh.

Abb. 8. Mauerwerk des Altarraums, Triumphbogens und Kirchenschiffs. Foto A. Balogh.

s hospodárskym užívaním farského dvora. Pod ňou sa nachádzala sutinová vrstva s kameňmi (101), súvisiaca so zánikom objektu. V interiéri svätyne sme pod ňou zachytili súvislú vrstvu z plochých lomových kameňov a sekundárne použitých kamenných platní (200). Interpretujeme ju ako poslednú dlážku stavby, ktorá však už v tom čase pravdepodobne slúžila ako hospodársky, a nie sakrálny objekt. $Z$ povrchu tejto dlážky sme získali mincu z roku 1858 . Pod touto dlážkou je vrstva planírky (102) a pod ňou už vrstva 103, súvisiaca s výstavbou svätyne. Do tejto vrstvy sú už zapustené hrobové jamy hrobov H2-4. Pod stavebnou vrstvou sa nachádza ílovitohlinité geologické podložie (106), ktoré hlbšie prechádza do vrstvy piesku (107). V severnom exteriéri svätyne sme rovnako zachytili navážkovú vrstvu (100). Pod ňou je vrstva (104), ktorá dokumentuje nárast terénu počas existencie objektu a pod ňou je zas exteriérová stavebná navážka (105). Zachytené murované konštrukcie v popisovanom profile zastupujú murivá svätyne (900), zvyškov staršieho, bližšie neidentifikovatel'ného objektu (901), murivo sakristie (902) a modernej prístavby/kúpel'ne fary (903). Recentnú konštrukciu predstavuje septik (904).

Po sondážnej časti výskumu, kedy sa nám podarilo odkryt' niekol'ko spomínaných, prevažne základových murív, sme pristúpili k plošnému odkryvu zvyškov kostola s cielom zistit' jeho celý pôdorys. V tejto etape výskumu sme zachovali profily niektorých sond. Vznikli nám tak tri sektory, v ktorých sme, okrem iného, zachytili aj úroveň dlážky hospodárskeho objektu, vzniknutého tu už po zániku kostola. Odkryli sme tak celý pôdorys základov západnej zvonice, celé pôdorysy svätyne, sakristie a severné murivo lode aj s jeho severozápadným nárožím bývalej lode. Okrem nich sme odkryli aj viacero fragmentov užších murív, ktorých funkcia je neistá a indikujú skôr provizórne stavebné riešenia (obr. 11).

Nepodarilo sa nám zachytit' južné murivo bývalej lode kostola a ani jeho juhozápadné nárožie, ba ani len negatív tohto múru, ktorý by sa črtal v inak sterilnom geologickom podloží. Neobjavila sa tu ani výraznejšia sutinová vrstva, ktorá by vznikla po jeho odstránení. Z tohto usudzujeme, že južné murivo lode kostola nebolo nikdy postavené, resp. dokončené. 
Rad - pôdorys svätyne

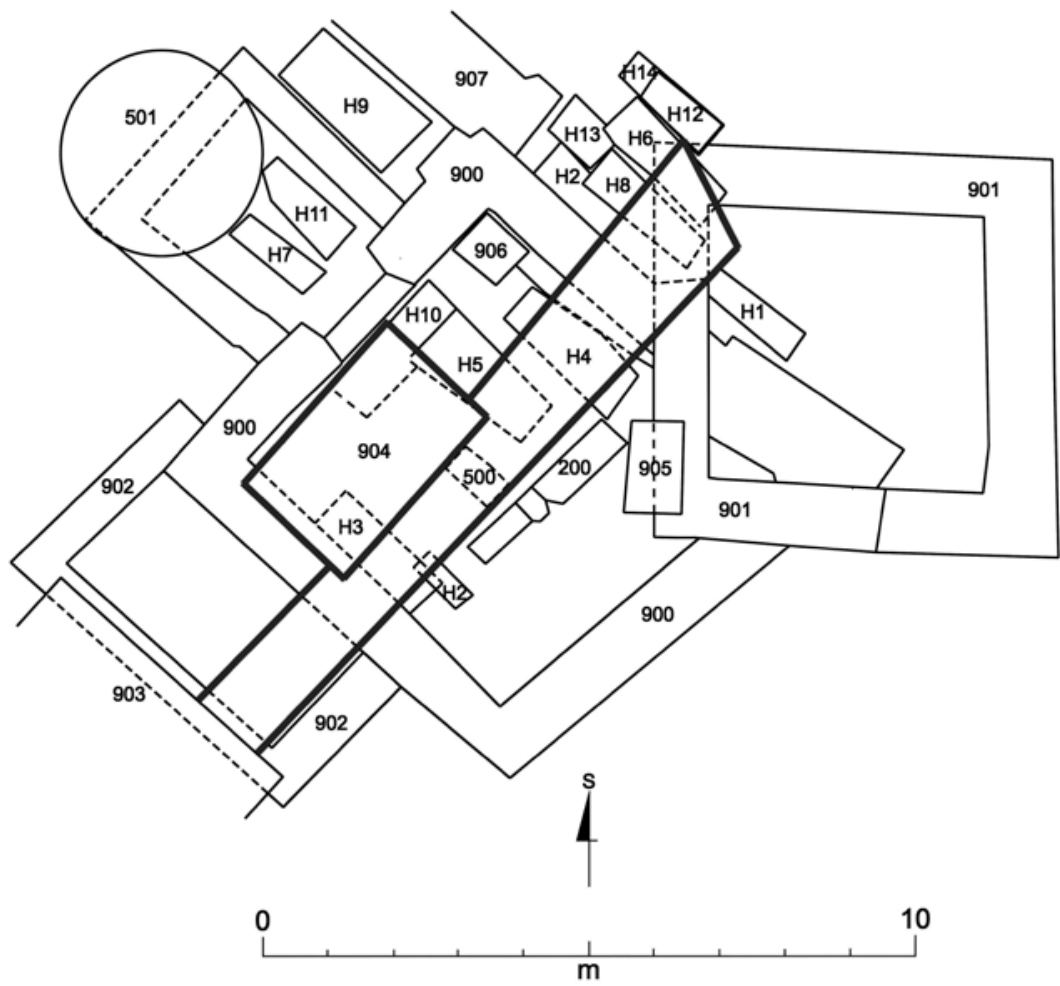

Obr. 9. Pôdorys svätyne s hrobmi. Autor A. Balogh.

Abb. 9. Grundriss des Altarraums mit Gräbern. Zeichnung A. Balogh.

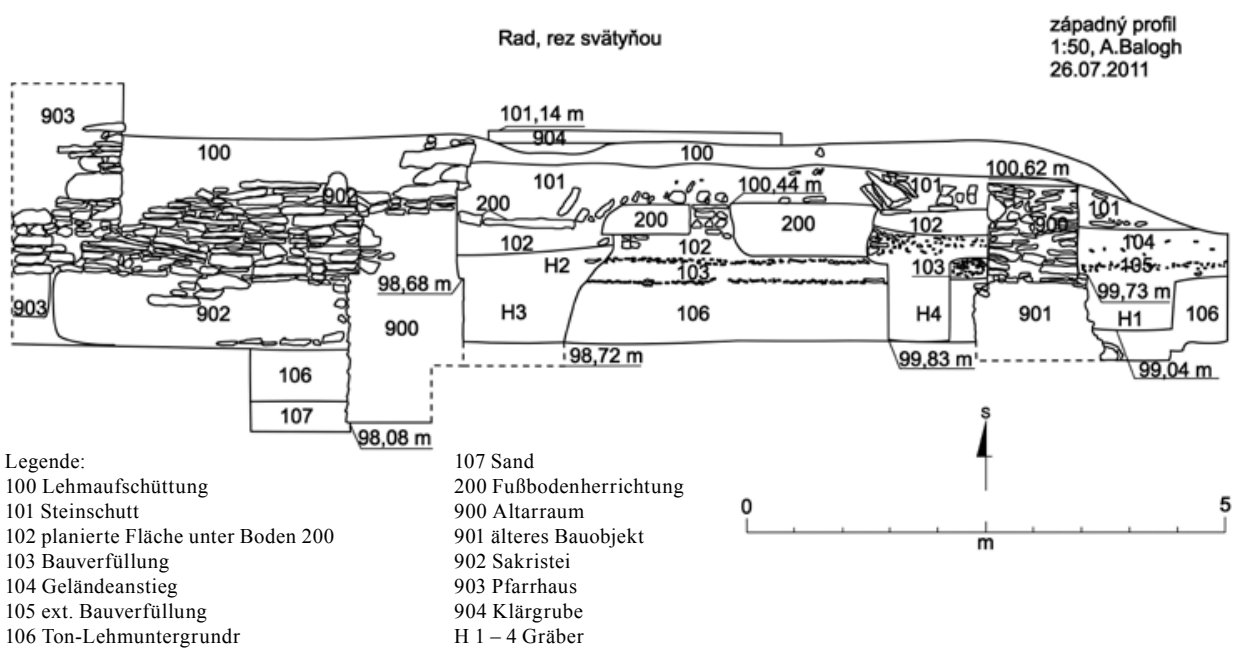

Obr. 10. Rez svätyňou. Autor A. Balogh.

Abb. 10. Profilschnitt durch den Altarraum. Zeichnung A. Balogh. 


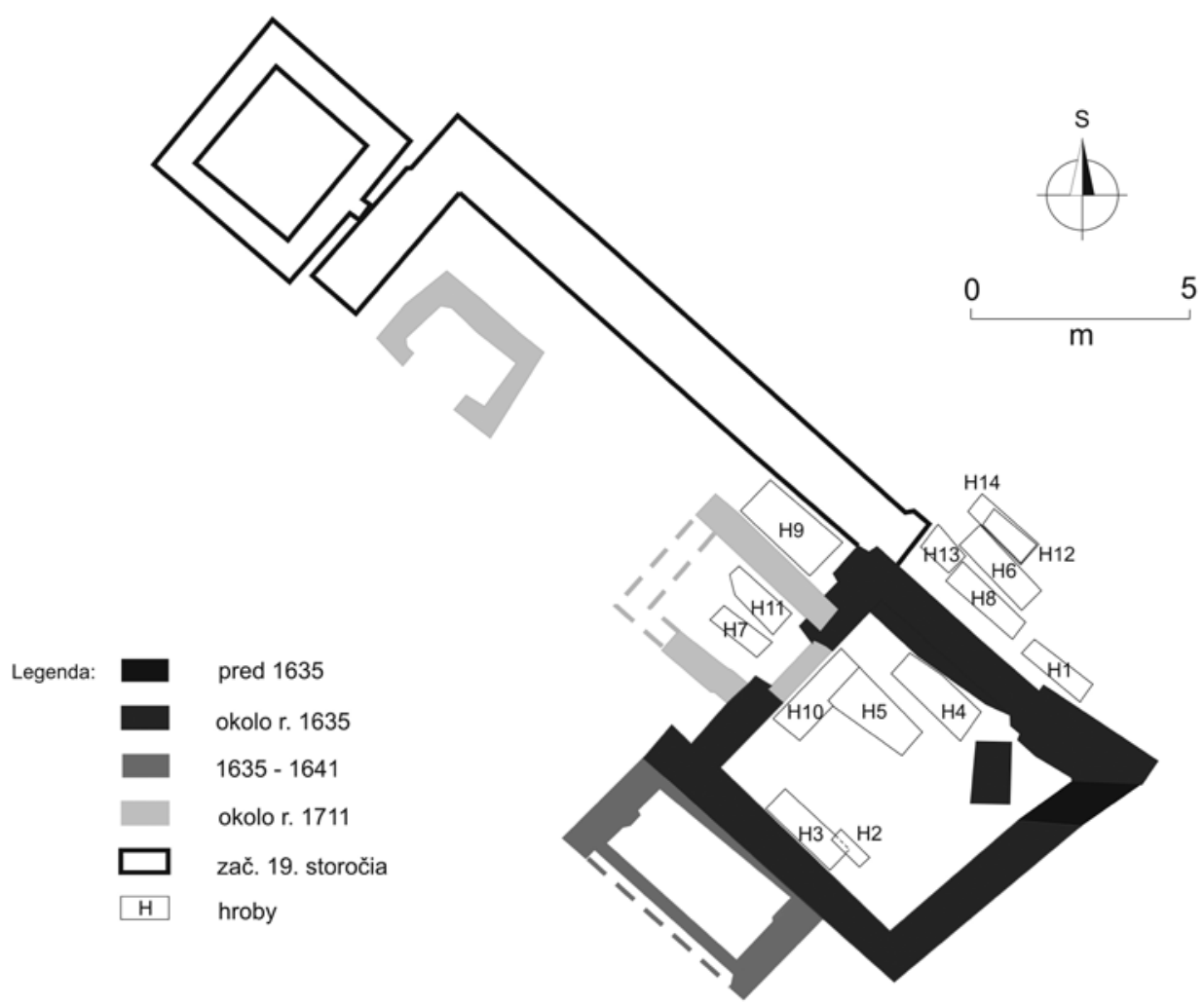

Obr. 11. Stavebné etapy výstavby kostola. Autor A. Balogh.

Abb. 11. Bauetappen der Errichtung der Kirche. Zeichnung A. Balogh.

Väčšinu nálezového fondu tvoria keramické črepy z tela nádob. Chronologicky možno všeobecne hnutel'né nálezy zaradit' do obdobia od 17. do 20. storočia. K najstarším keramickým nálezom možno zaradit’ črepy zo sondy č. 6 , ktoré pochádzajú z tela nádob s glazovanými okrajmi, a fragment dna s okrovým až čiernym výpalom bez glazúry. Drvivú väčšinu nálezov tvoria drobné úlomky tzv. kuchynskej keramiky, len rámcovo datovatel'nej do 18.-19. storočia. Nachádza sa v premiešaných vrstvách 100 a 101. Ku keramickým nálezom z týchto vrstiev patria aj úlomky rovnako datovaných kachlíc a fragment fajky. Z kovových nálezov sem patrí medený medailón z hrobu č. 1. s motívom Madony, datovatel'ný do 17. storočia (obr. 12). Ide o bežný artefakt, ktorý sa ako pamätný medailón predával na mariánskych odpustoch v 17.-18. storočí. Identický nález je popísaný napríklad z výskumu zaniknutého kostola cintorína v abovskej Felsőzsolce (Simonyi 2004, 181-182, 191) alebo z pohrebiska z 18. storočia v mad’arskom Višegráde (Kováts 2013, 7).

Napriek tomu, že prvý hrob na lokalite bol odkrytý počas výskumu kostola v roku 2011, d’alšie hroby sme skúmali až v nasledujúcich rokoch. V roku 2012 sme odkryli dva hroby v interiéri svätyne (H2, 3) a v roku 2013 d’alších 11 hrobov (H4-14). V rámci tejto etapy výskumu bolo preskúmaných aj niekol'ko zahíbených objektov, z ktorých za zmienku stojí mladšia murovaná studňa $\mathrm{v}$ tesnom susedstve kostola.

Samotné hroby boli podrobené súdnolekárskej expertíze, ktorú realizoval Ústav súdneho lekárstva Lekárskej fakulty Univerzity Pavla Jozefa Šafárika v Košiciach (Bobrov 2012, 2013). Z podrobných správ týchto expertíz vyplýva, že sa vo všetkých prípadoch jednalo o pohreby 


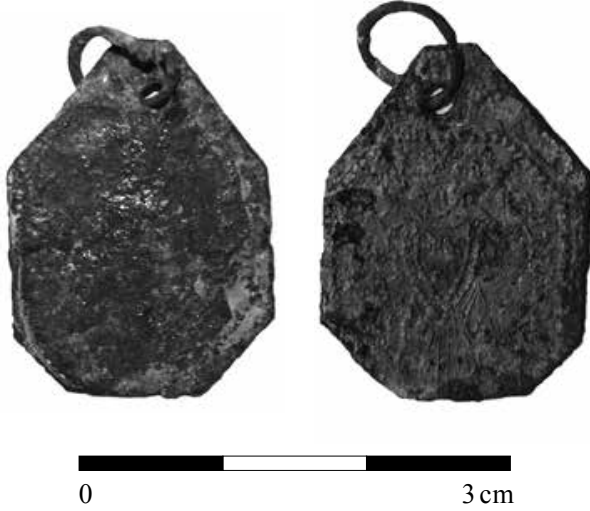

Obr. 12. Oktogonálny medailón z hrobu č. 1. Foto A. Balogh. Abb. 12. Oktogonales Medaillon aus Grab Nr. 1. Foto A. Balogh.

mužov vo veku 12 až 50 rokov, prevažne však vo veku okolo 30 rokov. Doba uloženia kostier v zemi bola určená na obdobie minimálne 300 rokov. U viac než polovice týchto mužov boli zistené zranenia, $\mathrm{z}$ ktorých viaceré viedli k ich násilnej smrti. Spomeňme niektoré z nich. Už pri hrobe č. 1 bola zistená zlomenina tela sánky a sečná rana pravej ruky. Bol taktiež zistený účinok mechanického násilia na oblast' krku, a to najpravdepodobnejšie udusením obesením, čo viedlo k rozostúpeniu krčných stavcov a následne aj $\mathrm{k}$ posmrtnému oddeleniu hlavy od tela. Pri hrobe č. 2 boli zistené minimálne 3 poranenia spôsobené zaživa, ktoré sa však nestihli zhojit': odlomenie zobákovitého výbežku na pravej lopatke, zlomenina tela pravej ihlice $v$ strednej tretine a vylomenie lonovej spony panvy. Ďalší muž vo veku 20-30 rokov z hrobu č. 5 zomrel následkom priečnej sečnej rany v oblasti tváre. Chlapec vo veku 12-16 rokov z hrobu č. 10 zomrel na následky zlomeniny čelovej kosti a muž vo veku 35-40 rokov z hrobu č. 9 mal zistenú zlomeninu krčného stavca, jeho pravej časti a zadného oblúka, čo je podl'a znalca charakteristické pre tzv. hangman fractures - zlomeniny obeseného.

Napriek pomerne t’ažkej interpretačnej situácii výskumu je možné, predovšetkým na základe vzt’ahov a štruktúry zachovaných murív, rekonštruovat' chronológiu výstavby skúmaných zvyškov architektúry (obr. 13). Oporu pre datovanie nám, žial', archeologické nálezy neposkytujú a nemožno sa opriet' ani o štýlovú stavebno-historickú analýzu, ked’že sa nezachovali ani

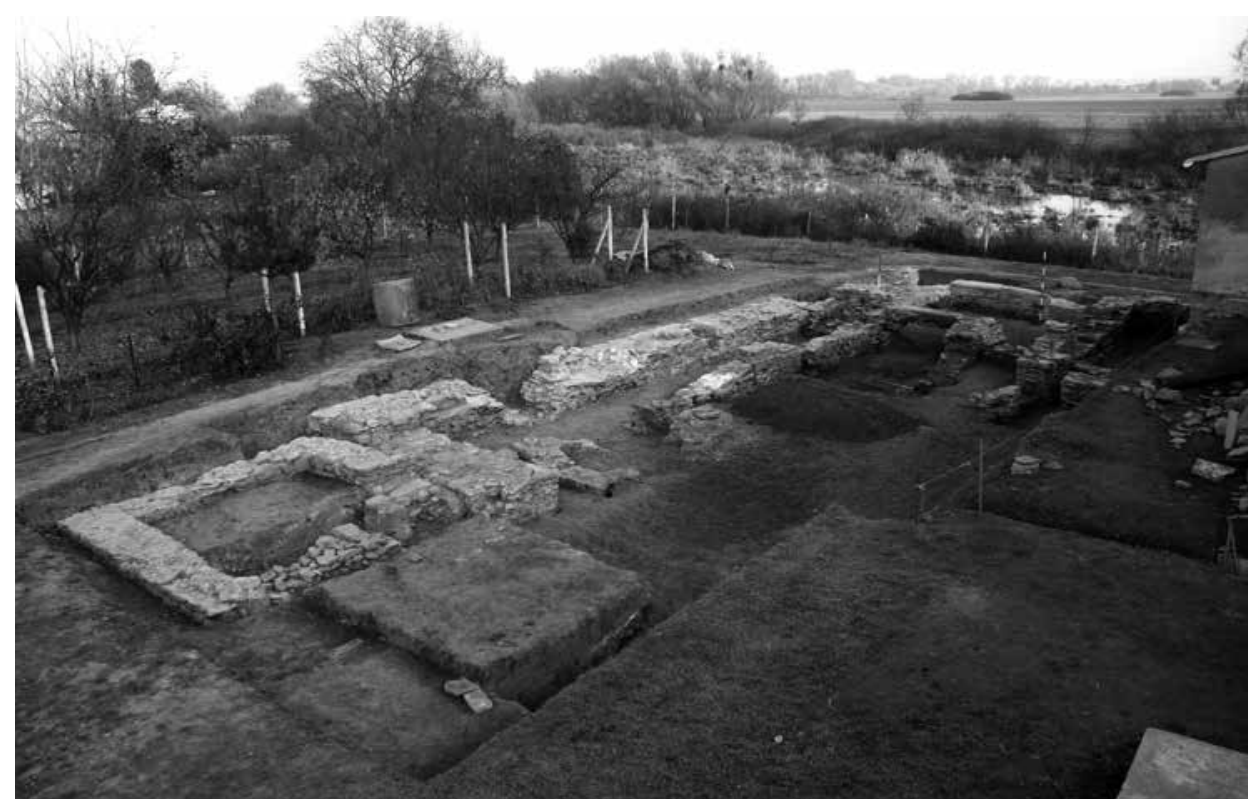

Obr. 13. Zvyšky kostola po ukončení výskumu. Foto A. Balogh.

Abb. 13. Überreste der Kirche nach Grabungsende. Foto A. Balogh. 


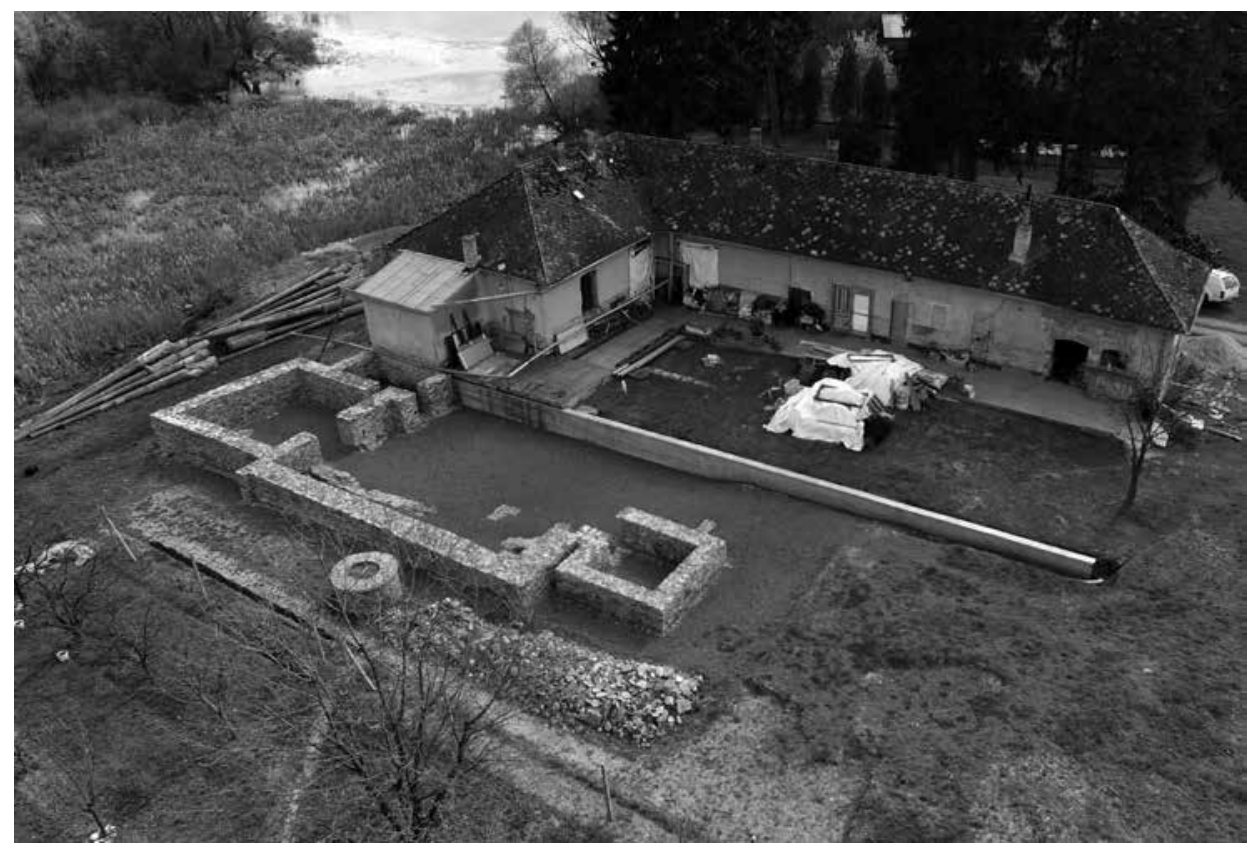

Obr. 14. Rekonštrukcia zvyškov kostola. Foto Herman Ottó Múzeum Miskolc (HU).

Abb. 14. Rekonstruktion der Überreste der Kirche. Foto Herman Ottó Múzeum Miskolc (HU).

fragmenty architektonického tvaroslovia. Oporu nám tak poskytujú predovšetkým spracované písomné pramene.

Ako najstaršia sa javí svätyňa kostola, ktorá bola pravdepodobne postavená tesne po príchode františkánov do Radu, to jest okolo roku 1635. Čiastočne bolo pri jej výstavbe využité aj murivo staršej architektúry, ktorú však nedokážeme bližšie identifikovat'. Krátko po výstavbe svätyne bola k nej z južnej strany pristavaná sakristia. Tieto dva priestory možno považovat' za provizórny sakrálny priestor, ktorý uvádza spomínaná vizitácia z roku 1641. Následne došlo k už opísaným udalostiam, ktoré viedli k prerušeniu fungovania kláštora, a teda aj d’alšej stavebnej činnosti.

K nasledujúcim, i ked' vel'mi skromným stavebným aktivitám podl'a nás došlo až v roku 1711, ked' sa bratia pokúsili kláštor obnovit's pomocou milodarov. Predpokladáme, že pred svätyňu postavili predsieň a o niečo d’alej malú zvonicu. Mohutné murivo lode a predstavanej veže už podl'a nás nesúvisia so stavebnou činnost'ou minoritského rádu. Túto stavebnú etapu nám pomohla datovat' minca $\mathrm{z}$ roku 1800 , nájdená $\mathrm{v}$ základovej ryhe muriva lode. $\mathrm{V}$ tom čase sa pravdepodobne katolícki veriaci pokúsili obnovit' stavbu kostola, snád' už aj ako farského svätostánku. Tieto práce možno prerušila mohutná povodeň blízkej Tice. A tak sa neskôr rozhodli postavit' svoj kostol na výhodnejšom mieste v strede obce, ktorý vysvätili v roku 1822 ako Kostol Najsvätejšej Trojice (Lenčiš 2006, 126). Z bývalého kláštora sa tak stala fara, ktorá slúži dodnes. Čo sa týka preskúmaných hrobov, a predovšetkým súdnolekárskych expertíz, možno dôvodne predpokladat', že sa tu s vel'kou pravdepodobnost'ou jedná o hroby mníchov, ktorých násilnú smrt' popisujú historické pramene. V roku 2014 rímskokatolícka farnost' v Rade začala s postupnou konzerváciou a náznakovou rekonštrukciou zvyškov murív kostola (obr. 14). 


\section{Pramene a literatúra}

ASPF Roma, Archivio storico de propaganda Fide Roma, fond Acta Sacrae Congregationis, sign. 14.

ASPF Roma, Archivio storico de propaganda Fide Roma, fond Scritture originali riferite nelle congregazioni generali, sign. 28, ASPF Roma SOCG 75, ASPF Roma SOCG 77, ASPF Roma SOCG 78, ASPF Roma SOCG 79, ASPF Roma SOCG 80, ASPF Roma SOCG 81, ASPF Roma SOCG 82, ASPF Roma SOCG 83, ASPF Roma SOCG 218.

ASPF Roma, Archivio storico de propaganda Fide Roma, fond Scritture riferite nei Congressi, sign. Missioni, Miscelanea 10.

BOBROV, N., 2012, 2013: Odborné vyjadrenie k súdnolekárskej expertíze kostrových pozostatkov nájdených pri archeologickom výskume na farskom dvore v obci Rad (okr. Trebišov). UPJŠ Košice.

FRANCHINI, G., Manoscritti diversi ad uso storico. AGOFMConv. Roma, Archivio Generale dell' Ordine dei Frati minori Conventuali Roma, fond Cl. - Manocritti, sign. III, 19.

GAČKOVÁ, L., ed., 2004: Archeologické dedičstvo Zemplína. Michalovce.

HIŠEM, C., 2006: Dejiny Košického arcibiskupstva. Prešov.

KNÁISZ, M., 1803: Chronologo - Provinciale Ordinis F. F. Minorum S. Francisci Conventualium Provinciae Hungariae, et Transilvaniae, nunc S. Elisabeth Reginae nuncupatae. Posoni.

KOVÁTS, I., 2013: 18. századi temető Visegrád központjából. Magyar régészet online magazin. 2013 ősz.

LENČIŠ, Š., 2006: Katalóg Košickej arcidiecézy. Prešov.

MATERNIK, A., 1754: Brevis Relatio Conventuum et Residentiarum Alma Provinciae Sancyae Elisabeth in Hungaria Transylvania partibusque annexis posliminio aquisitorum cum suis Fundationibus etc. AGOFMConv. Roma, Archivio Generale dell' Ordine dei Frati minori Conventuali Roma, fond S/XXX-A, sign. 3.

MVS: Monumenta Vaticana Slovaciae. Tomus 1. Rationes collectorum pontificiorum in annis 1332-1337. (Sedlák, V., ed.). Trnavae - Romae 2008.

PÁL, E., 1744: Inventarium Residentiae Radensis ad SSS. Trinitatem Anno 1744 Die 12 Aprilis. Ulož. v dokumentácii Római Katolikus Egyházi Gyüjtemény v Sárospataku (HU), sine sign.

- 1744a: Refero nihilominus R.mae Paternitati Vestrae. AGOFMConv. Roma, Archivio Generale dell'Ordine dei Frati minori Conventuali Roma, fond S/XXX-A, sign. 2.

Relatio de Statu Provinciae Hungariae ordinis Minorum S. Francisci Conventualium ab Anno 1526 usque ad Annum 1711. APOFMConv. Miskolc, Archivium provincialis Ordinis Fratrum minorum Conventualium Miskolc, sine sign.

SCALIMOLI, A., Relatione de stato Franciscano conventuale nella provincia d'Ungaria. AGOFMConv. Roma, Archivio Generale dell' Ordine dei Frati minori Conventuali Roma, fond S/XXX-A, sign. 1.

SIMONYI, E., 2004: Középkori templom és temető Felsőzsolca-Nagyszilváson, HOMÉ 43, 161-197.

SLIVKA, M.-VALLAŠEK, A., 1983: Stredoveké šl'achtické sídla v južnej časti Zemplína, Nové obzory, č. 25, 145-190.

SÚPIS III., 1969: Súpis pamiatok na Slovensku III. Bratislava.

SZIRMAY, A., 1804: Notitia historica comitatus Zempléniensis. Pest.

ULIČNÝ, F., 2001: Dejiny osídlenia Zemplínskej župy. Michalovce.

\section{Zusammenfassung}

\section{Grabung an einer verschwundenen Minoritenkirche mit Friedhof in Rad (Bezirk Trebišov)}

Die Gemeinde Rad befindet sich im südlichen Teil des Ostslowakischen Tieflandes an der Flussaue der Latorica, die ab dem Zusammenfluss mit der Ondava den Fluss Bodrog bildet. Die untersuchte untergegangene Kirche mit dem Friedhof befindet sich im Bereich des heutigen Pfarrgartens des römisch-katholischen Pfarrhauses im nordöstlichen Teil der Gemeinde. Östlich der Fundstelle befindet sich in dichter Nachbarschaft die Wasserfläche eines ursprünglich Tice genannten toten Flussarmes. Die Anfänge der Ordensgemeinschaft der Minoriten (des konventualischen Zweigs des Franziskanerordens) in Rad fällt in die Zeit der Rekatholisierungsmissionen, die vom Heiligen Stuhl mittels der römischen Kongregation für die Verbreitung des Glaubens (Congregatio de Propaganda Fide) organisiert wurde. Die Gründung des Klosters wird in den Herbst des Jahres 1637 datiert. Den Gründungsurkunden nach sollen in Rad vier 
Ordensbrüder gelebt haben. Das Kloster hatte den Status einer Residenz. Während des Ständeaufstandes von Georg I. Rákóczi in den Jahren 1643-1645 wurden die Minoriten für mehrere Jahre aus Rad vertrieben. Andere bewaffnete Überfälle auf die Residenz registrieren wir im Jahr 1690, als die Ordensbrüder von Rákóczis Soldaten überfallen wurden, weitere dann in den neunziger Jahren des 17. Jahrhunderts, als die Residenz wieder von den Aufständischen mit Graf Franz von Tokay an der Spitze geplündert wurde. Jeder dieser Überfälle kostete mehrere Ordensbrüder das Leben. Nach dem Ende von Rákóczis Aufstand hat man versucht, die Residenz mithilfe von Spenden wiederaufzubauen, jedoch wurden die Ordensbrüder im Jahr 1767 in die nahegelegene Gemeinde Brehov umgesiedelt. Bei der archäologischen Grabung wurden die Überreste einer verschwundenen Kirche freigelegt, welche alle Merkmale dafür aufweist, dass die Bautätigkeiten unterbrochen und nicht zu Ende geführt wurden. Als ältester Teil erscheint der Altarraum der Kirche, der wahrscheinlich unmittelbar nach der Ankunft der Franziskaner in Rad errichtet wurde, d.h. um das Jahr 1635. Kurz nach dem Bau des Altarraums wurde an dessen Südseite die Sakristei angebaut. Diese beiden Räume können als provisorischer sakraler Raum angesehen werden, der im Protokoll einer Visitation aus dem Jahr 1641 aufgeführt wird. $\mathrm{Zu}$ weiteren, wenn auch sehr bescheidenen Bauaktivitäten kam es unseren Erkenntnissen nach erst wieder im Jahr 1711, als von den Ordensbrüdern versucht wurde, das Kloster mithilfe von Spenden wiederaufzubauen. Wir vermuten, dass man vor den Altarraum einen Vorraum gebaut hat und etwas weiter ein kleiner Glockenturm errichtet wurde. Das mächtige Mauerwerk des Schiffs und des davor stehenden Turms hängt unserer Meinung nach bereits nicht mehr mit der Bautätigkeit des Minoritenordens zusammen. Die Datierung dieser Bauetappe konnte anhand einer im Fundamentgraben des Schiffs gefundenen Münze aus dem Jahr 1800 erfolgen. In dieser Zeit wurde von den katholischen Gläubigen wahrscheinlich versucht, das Kirchengebäude wiederaufzubauen, dies bereits als Pfarreikirche. Diese Arbeiten wurden möglicherweise von einem mächtigen Hochwasser der nahegelegenen Tice unterbrochen. Und so hat man später entschieden, an einer günstigeren Stelle im Zentrum der Gemeinde eine Kirche zu errichten, die im Jahr 1822 dann als Kirche zur Allerheiligsten Dreifaltigkeit eingeweiht wurde (Lenčiš 2006, 126). Aus dem ehemaligen Kloster wurde ein Pfarrhaus, das bis heute seinen Dienst tut. Was die untersuchten Gräber und vor allem die gerichtsmedizinischen Expertisen betrifft, kann man begründetermaßen davon ausgehen, dass es sich hier mit hoher Wahrscheinlichkeit um die Gräber der Mönche handelt, deren gewaltsamer Tod in den historischen Quellen beschrieben wird.

Mgr. Peter Tajkov, PhD., Fakulta umení Technickej univerzity v Košiciach, Letná 9, SK 04200 Košice, Slovenská republika,tajkov@yahoo.co.uk

ThLic. Jozef Sukeník, Rehol’a menších bratov konventuálov - minoritov, Nám. sv. Františka 4, SK 84104 Bratislava, Slovenská republika,sukenik.jozef@gmail.com 
